\title{
Long-Term Response Patterns of Tallgrass Prairie to Frequent Summer Burning
}

\author{
E. Gene Towne ${ }^{1}$ and Ken E. Kemp ${ }^{2}$ \\ Authors are ${ }^{1}$ Konza Prairie Fire Chief, Division of Biology, and ${ }^{2}$ Professor, Department of Statistics, Kansas State University, Manhattan, KS 66506, USA
}

\begin{abstract}
Knowledge of how tallgrass prairie vegetation responds to fire in the late growing season is relatively sparse and is based upon studies that are either spatially or temporally limited. To gain a more robust perspective of vegetation response to summer burning and to determine if repeated summer fire can drive vegetational changes in native tallgrass prairie, we evaluated species cover and richness over a 14-yr period on different topographic positions from ungrazed watersheds that were burned biennially in the growing season. We found that annual forbs were the primary beneficiaries of summer burning, but their fluctuations varied inconsistently among years. Concomitantly, species richness and diversity increased significantly with summer burning but remained stable through time with annual spring burning. After $14 \mathrm{yr}$, species richness was $28 \%$ higher in prairie that was burned in the summer than in prairie burned in the spring. Canopy cover of big bluestem (Andropogon gerardii Vitman) and Indiangrass (Sorghastrum nutans [L.] Nash) increased significantly over time with both summer and spring burning, whereas heath aster (Symphyotrichum ericoides [L.] Nesom), aromatic aster (Symphyotrichum oblongifolium [Nutt.] Nesom), and sedges (Carex spp.) increased in response to only summer burning. Kentucky bluegrass (Poa pratensis L.) cover declined in both spring-burned and summer-burned watersheds. Repeated burning in either spring or summer did not reduce the cover or frequency of any woody species. Most perennial species were neutral in their reaction to summer fire, but a few species responded with large and inconsistent temporal fluctuations that overwhelmed any clear patterns of change. Although summer burning did not preferentially encourage spring-flowering forbs or suppress dominance of the warm-season grasses, it is a potentially useful tool to increase community heterogeneity in ungrazed prairie.
\end{abstract}

\section{Resumen}

El conocimiento de cómo la vegetación de pasto alto responde al fuego en la temporada de crecimiento tardía es relativamente escaso y se basa en estudios que son espacialmente o temporalmente limitados. Para obtener una perspectiva más robusta de la respuesta vegetativa a la quema de verano, y para determinar si el fuego repetido de verano conduce a cambios vegetacionales en la pradera de pasto alto nativo, nosotros evaluamos la riqueza y la cobertura de especies por un periodo de 14 años en diferentes posiciones topográficas de las cuencas hidrográficas sin pastar que fueron quemadas cada dos años en la temporada de crecimiento. Nosotros encontramos que los arbustos anuales fueron los principales beneficiarios de la quema de verano, pero sus fluctuaciones variaron inconsistentemente entre los años. Al mismo tiempo, la diversidad y la riqueza de especies se incrementaron significativamente con la quema de verano, pero permanecieron estables a través del tiempo con la quema anual de primavera. Después de 14 años, la riqueza de especie fue $28 \%$ más alta en la pradera que fue quemada en el verano que la pradera quemada en la primavera. La cobertura de dosel de la pitilla grande [Andropogon gerardii Vitman] y el zacate indio [Sorghastrum nutans $\{\mathrm{L}$.\} Nash] se incrementó significativamente a través del tiempo con ambas quemas de primavera y de verano, mientras que la "heath aster" (Symphyotrichum ericoides [L.] Nesom), "aromatic aster" (S. oblongifolium [Nutt.] Nesom), y las cortaderas (Carex spp.) aumentaron en respuesta solo a la quema de verano. La cobertura de la hierba azul de Kentucky (Poa paratensis) declinó en ambas quemas de primavera y verano en las cuencas hidrográficas. Las quemas repetidas en cada primavera ó verano no redujeron la cobertura ó frecuencia de cualquier especie leñosa. Muchas especies perennes fueron neutrales en su reacción al fuego de verano, pero unas pocas especies respondieron con fluctuaciones temporales grandes e inconsistente que abruman algunos patrones claros de cambio. Aunque la quema de verano no fomenta preferentemente a los arbustos que florecen en primavera ó suprimen la dominancia de las hierbas de la temporada cálida, es una herramienta potencialmente útil para incrementar la heterogeneidad de la comunidad.

Key Words: burn season, fire ecology, grassland vegetation, growing-season fire

\section{INTRODUCTION}

Tallgrass prairie is a fire-dependent ecosystem that is typically burned in the dormant season (Anderson et al. 1970; Engle and

The National Science Foundation Long-Term Ecological Research Program and the Kansas Agricultural Experiment Station provided support for this project.

Correspondence: E. Gene Towne, Division of Biology, Kansas State University, Manhattan, KS 66506, USA. Email: egtowne@ksu.edu

Manuscript received 7 March 2008; manuscript accepted 3 July 2008.
Bidwell 2001). Frequent dormant-season burning of ungrazed tallgrass prairie, however, increases canopy cover of perennial warm-season grasses (Towne and Kemp 2003) and reduces species diversity (Collins 1992). Because prairie remnants, restoration sites, conservation preserves, and other ungrazed prairies are usually characterized by low species richness and high amounts of warm-season grasses (Kindscher and Tieszen 1998; Polley et al. 2005), there often is reluctance to burn them frequently enough to prevent invasion of woody species (Bragg and Hulbert 1976). Burning ungrazed prairies in the late 
growing season (i.e., summer burning) has been proposed as an alternative to reduce dominance of the warm-season grasses and favor plants that may otherwise be adversely affected by dormant-season burns (Howe 1994, 1995; Copeland et al. 2002).

Historically, North American prairies burned periodically in the summer from both anthropogenic ignitions and lightning strikes (Bragg 1982; Higgins 1984; Pyne 1994). Growingseason fires are utilized in some ecosystems to control undesirable species (Emery and Gross 2005; Simmons et al. 2007; Parmenter 2008). Although tallgrass prairie is traditionally burned in the spring, documenting how the vegetation responds to fire in the growing season is important for predicting plant community changes following accidental or prescribed summer burning. Engle et al. (1993, 1998) concluded that tallgrass prairie is resilient to change, and that fire in the growing season would have a relatively minor and short-lived influence on the plant community. Geographic location, topoedaphic factors, or yearly climatic variability, however, can affect how plants respond to fire, and the effect of recurrent summer burning on most prairie plants is either inconsistent or unknown (Engle et al. 2000; Engle and Bidwell 2001). Most research on plant compositional changes from summer burning has occurred in locations that were not lateseral tallgrass prairie (e.g., early successional fields [Engle et al. 2000], midsuccessional prairie [Engle et al. 1998], and restoration sites [Howe 1994, 1995; Copeland et al. 2002]). In addition, characterizations of how tallgrass prairie responds to summer fire have been short-term studies in small plots where spatial variability is limited and burn conditions are likely different from large-scale areas. Thus, our objectives were to evaluate the long-term effects of recurring summer fire on plant community composition, and to determine if repeated summer burning would drive vegetational changes in native tallgrass prairie. Here, we test the hypothesis that the dominant warm-season grasses would decline through time from repeated summer burning with the concomitant expected increase in the forb population.

\section{METHODS}

\section{Study Site}

We conducted the research on Konza Prairie Biological Station (a preserve of The Nature Conservancy managed by the Division of Biology at Kansas State University), a 3487-ha tallgrass prairie located in the Flint Hills of northeastern Kansas (lat $39^{\circ} 05^{\prime} \mathrm{N}$, long $96^{\circ} 35^{\prime} \mathrm{W}$ ). Hilly topography and shallow soils have prevented extensive cultivation of the Flint Hills, enabling it to comprise the largest remnant tracts of native tallgrass prairie in North America. To study how fire frequency and seasonality affects grassland vegetation, Konza Prairie is parceled into numerous watersheds that provide large experimental units subjected to different fire regimes. Topographically, the watersheds comprise upland plateaus, rocky hillsides, and fertile lowlands. The upland topographic positions have relatively shallow soils that are silty clay loams overlying limestone and shale layers (Udic Argiustolls, Florence series), whereas the lowland soils are deeper colluvial and alluvial deposits (Pachic Argiustolls, Tully series). Warm- season perennial grasses (primarily big bluestem [Andropogon gerardii Vitman], Indiangrass [Sorghastrum nutans [L.\} Nash], and little bluestem [Schizachyrium scoparium [Michx.\} Nash]) dominate the vegetation on both topographic positions, but many plant species that are characteristic of midgrass and shortgrass prairies thrive on the xeric upland soils. Forb species constitute more than $75 \%$ of the vascular plant diversity on Konza Prairie (Towne 2002). Botanical nomenclature follows the US Department of Agriculture Natural Resources Conservation Service (2008) PLANTS database.

Climate for the area typically has hot summers, cold winters, and moderately strong surface winds. Annual precipitation at Konza Prairie has averaged $826 \mathrm{~mm}$ in the previous $25 \mathrm{yr}$, with approximately $75 \%$ falling in the April through September growing season. The frost-free season lasts approximately $180 \mathrm{~d}$, with 16 October as the average date for the first killing freeze.

\section{Experimental Design}

In 1994, we selected two watersheds (average size $=21$ ha) for the summer burn treatment and two adjacent watersheds (average size $=25 \mathrm{ha}$ ) for a comparative spring burn treatment. All four watersheds had not been grazed in more than $20 \mathrm{yr}$, and had been burned on average every $3 \mathrm{yr}$ in the spring. The two watersheds selected for the summer burn treatment were last burned in 1991. Litter accumulations and senescent vegetation are not always sufficient to sustain an annual summer burn regime, so the experimental design entailed burning during the growing season on a biennial frequency. We compared temporal changes in the vegetation from summer burning with traditional annual spring burning. However, because the effects of spring burning on the composition of tallgrass prairie are well documented (Aldous 1934; Abrams and Hulbert 1987; Gibson and Hulbert 1987; Towne and Kemp 2003), the primary focus of this study was on vegetational trends in the summer burn treatment.

We initiated the summer burns on 2 September 1994, but a wildfire in February 1996 burned both watersheds and interrupted the planned design. We resumed summer burning of the watersheds on 31 July 1997, with subsequent burns occurring on 26 July 1999, 14 August 2001, 24 July 2003, and 29 July 2005. Timing of the burns depended upon weather conditions that would ensure a safe and controlled fire, but we conducted all burns when the ambient temperatures were between $28^{\circ} \mathrm{C}$ and $34^{\circ} \mathrm{C}$, relative humidity was between $45 \%$ and $60 \%$, and wind speeds ranged from $15 \mathrm{~km} \cdot \mathrm{h}^{-1}$ to $30 \mathrm{~km} \cdot \mathrm{h}^{-1}$. Despite environmental conditions favorable for burning, high moisture content in the green plant tissues impeded fire intensity and produced relatively slow-moving head-fires. Dead standing stems and unburned detritus patches were commonplace after all of the summer burns. Fuel-load estimates are not available for all years, but the accumulated litter and aboveground dried biomass before burning in 1997 , 1999,2001 , and 2003 averaged $539 \pm 16 \mathrm{~g} \cdot \mathrm{m}^{-2}$ (mean $\pm \mathrm{SE}$ ) on upland sites and $654 \pm 18 \mathrm{~g} \cdot \mathrm{m}^{-2}$ on lowland sites in the two summer-burned watersheds.

The spring-burned watersheds were burned annually in midto late April beginning in 1994. Although not measured, fire intensity was relatively high and combustion of plant material 
was complete. From 1994 to 2002, annual net primary production in these two watersheds averaged $361 \pm 6 \mathrm{~g} \cdot \mathrm{m}^{-2}$ on upland sites and $525 \pm 10 \mathrm{~g} \cdot \mathrm{m}^{-2}$ on lowland sites.

\section{Vegetation Sampling}

Collection of plant species data from all four watersheds began in 1994 . We surveyed the vegetation in $10-\mathrm{m}^{2}$ permanently marked plots that were evenly spaced along four randomly located 50-m long transects on both upland and lowland topographic positions $\left(n=20\right.$ plots $\cdot$ topographic position ${ }^{-1}$. watershed ${ }^{-1}$ ). Every year, we estimated the canopy cover of all vascular plant species in a circular area within each plot by using a modified Daubenmire cover scale (Bailey and Poulton 1968). All plots were surveyed in June and either in August, or immediately before the summer burn in years that the watersheds were burned. For each species, the maximum cover value from the combined June and August surveys was used for further analyses. Percentage of canopy cover for individual species was calculated by converting each Daubenmire scale value to the midpoint of its cover range and then averaging across the 20 plots for each topographic position. Thus, annual percentage values for each burn treatment represent the mean of 40 plots from the two replicate watersheds, or 80 plots if the topographic positions were combined.

We calculated species diversity for each topographic position with the Shannon index $\left(H^{\prime}=-\Sigma p_{i} \times \ln p_{i}\right.$, where $p_{i}=$ the proportional canopy cover for each species). Species richness is defined as the cumulative number of vascular plant species detected in the 20 plots on each topographic position $\left(200-\mathrm{m}^{2}\right.$ survey area). To detect changes in diminutive and low-density species, we also calculated frequency of occurrence (the proportion of plots on each topographic position where the species occurred).

\section{Data Analyses}

We analyzed temporal trends in the vegetation from 1994 to 2007 for both spring and summer burning, but excluded 1996 and 1997 data because the February 1996 wildfire confounded burn treatment effects.

We analyzed the data using a split-plot, repeated-measures, mixed-model analysis of variance. The treatment structure was a 3-way factorial, with burn season, topographic position, and year as fixed effects. Watershed was a random effect and was the whole-plot experimental unit for burn treatment; topographic position was the subplot factor; and years were the repeated measures. For the analyses, there were two watersheds burned in each burn season, two topographic positions, and $12 \mathrm{yr}$ of data. We tested for linear and quadratic temporal trends in the canopy cover for each species using polynomial contrasts, and tested for trend interactions with burn season and topographic position. This allowed us to test if the linear and quadratic responses were consistent over time for the two burn treatments and whether the response over years was consistent between the two topographic positions. For species that were predominantly or uniquely site-specific in their occurrence, analyses were restricted to the appropriate topographic position. The primary emphasis in our statistical approach was to determine if burn season caused a significant change over time. Thus, we considered the presence of a significant quadratic effect, a significant linear effect, or both, to be evidence of a temporal change due to the burn treatment.

All species with greater than $2 \%$ cover and 20\% mean frequency were analyzed. Canopy cover and frequency proportions were arcsine square-root transformed for statistical analyses; however, for clarity in interpreting actual values found in the field, we back-transformed the means and standard errors for presentation in the text, tables, and figures. We used SAS Proc Mixed (Littell et al. 2006) with the Kenward-Roger correction for correlated errors to the denominator degrees of freedom to analyze the data, and used a 0.05 type I error rate for all significance tests.

\section{RESULTS}

\section{Warm-Season Grasses}

The response of big bluestem to burn season was differentially affected by topographic position. Summer burning increased $(P<0.0005)$ big bluestem cover linearly on lowland sites (Fig. 1A), but did not significantly change cover over time on upland sites (Fig. 1B). In comparison, spring burning increased $(P<0.001)$ cover in a curvilinear pattern on both topographic locations. After $14 \mathrm{yr}$, however, average big bluestem cover was not different between summer burning and spring burning on either lowland sites $(53.6 \%$ vs. $52.5 \pm 0.3 \%$, respectively) or upland sites $(43.6 \%$ vs. $48.1 \pm 0.3 \%$, respectively). Indiangrass cover increased linearly $(P<0.05)$ on both topographic positions in response to either burn season (Fig. 1C); but the rate of increase was greater in response to spring burning, and by the end of the study, Indiangrass cover was significantly higher in spring-burned watersheds $(40.4 \pm 0.2 \%)$ than in summer-burned watersheds $(20.3 \pm 0.2 \%)$. The canopy cover of all other warm-season grass species, including little bluestem, did not change significantly over time from repeated summer burning. However, spring burning caused a linear $(P<0.0001)$ increase in the cover of switchgrass (Panicum virgatum L.) on lowland sites, and a marginal decrease $(P<0.10)$ in the cover of tall dropseed (Sporobolus compositus [Poir.] Merr.) on both topographic positions (Table 1). Sideoats grama (Bouteloua curtipendula [Michx.] Torr.) cover was not affected significantly by burning in either season, but its eventual increase on upland sites burned in the summer (from $3.3 \pm 1.6 \%$ in 1994 to $20.2 \pm 1.6 \%$ in 2007 ) was noteworthy (Table 1).

Depending upon topographic position, summer burning increased $(P<0.05)$ the frequency of little bluestem, Indiangrass, side-oats grama, and tall dropseed between 1994 and 2007 (Table 2). In comparison, little bluestem was the only warm-season grass that increased significantly in frequency with annual spring burning.

\section{Cool-Season Graminoids}

The response of sedges (Carex spp. and Cyperus lupulinus [Sporeng.] Marcks) to summer burning were not adequately characterized with either linear or curvilinear curves. With summer burning, sedge cover declined initially, remained stable for several years, and then increased and leveled off at a higher plateau. On lowland topographic sites, sedge cover was not significantly different between the burn treatments until 2002, 

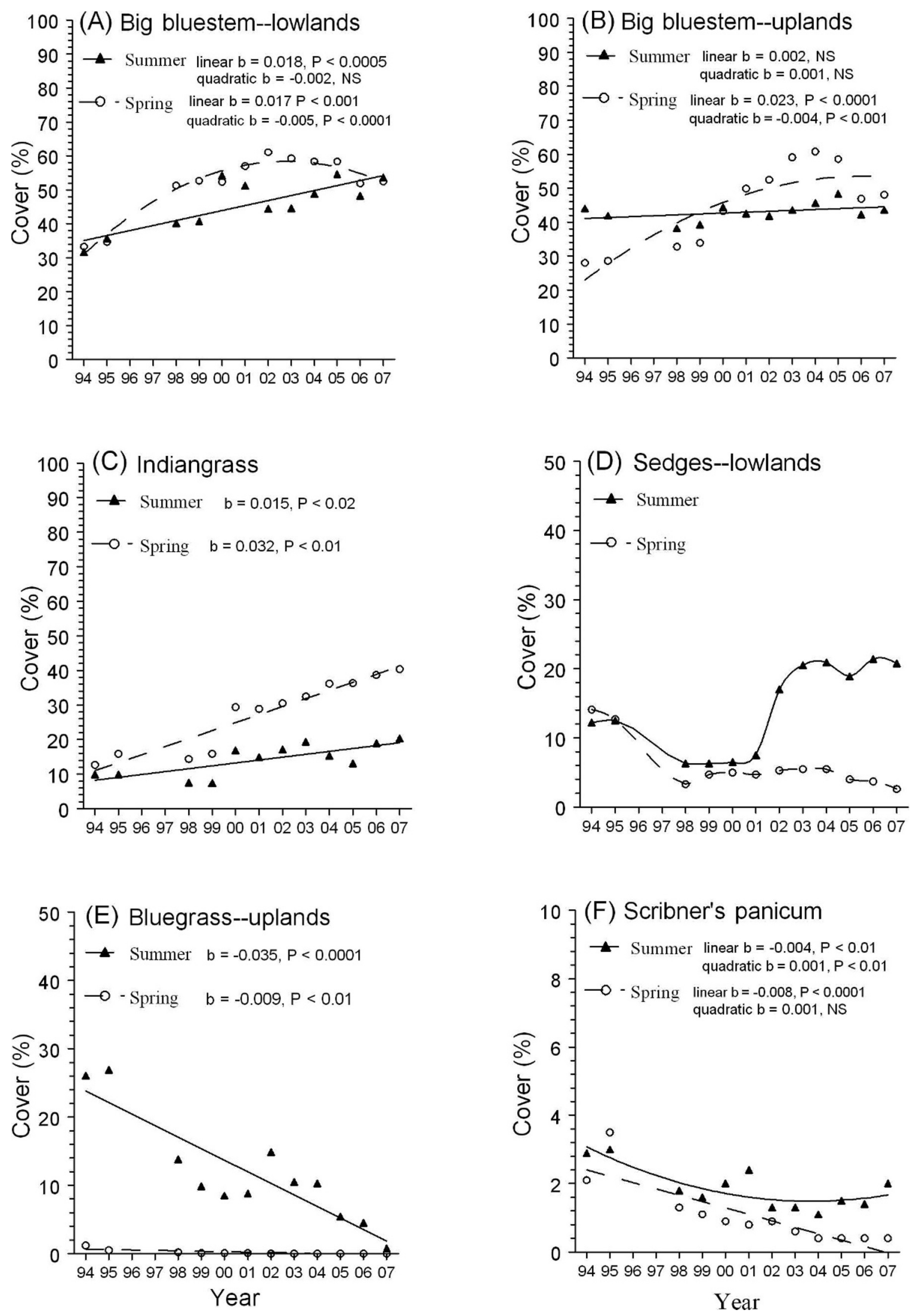

Figure 1. Temporal trends in canopy cover for various graminoid species in response to summer and spring burning of ungrazed tallgrass prairie. For those graphs that are for a specific topographic position, the values for each burn treatment represent the mean of 40 plots; otherwise, the values represent the mean of 80 plots from the combined upland and lowland topographic positions in two watersheds. Data for 1996 and 1997 are excluded because of a wildfire. Scaling of the $y$-axis varies among graphs. 
Table 1. Canopy cover comparisons between the first and last year of the study in spring-burned and summer-burned ungrazed tallgrass prairie on upland and lowland topographic positions for all species with $>2 \%$ cover.

\begin{tabular}{|c|c|c|c|c|c|c|c|c|}
\hline \multirow[b]{3}{*}{ Species } & \multicolumn{4}{|c|}{ Spring-burned (\%) } & \multicolumn{4}{|c|}{ Summer-burned (\%) } \\
\hline & \multicolumn{2}{|c|}{ Uplands } & \multicolumn{2}{|c|}{ Lowlands } & \multicolumn{2}{|c|}{ Uplands } & \multicolumn{2}{|c|}{ Lowlands } \\
\hline & 1994 & 2007 & 1994 & 2007 & 1994 & 2007 & 1994 & 2007 \\
\hline \multicolumn{9}{|l|}{ Graminoids } \\
\hline Andropogon gerardii & 28.0 & $48.1^{1}$ & 33.3 & $52.5^{2}$ & 44.0 & 43.6 & 31.7 & $53.6^{2}$ \\
\hline Bouteloua curtipendula & 11.8 & 13.5 & 1.1 & 0.1 & 3.3 & 20.2 & 1.0 & 0.6 \\
\hline Carex spp. & 4.0 & 1.3 & 14.1 & $2.6^{3}$ & 13.1 & $22.9^{2}$ & 12.2 & 20.8 \\
\hline Dichanthelium oligosanthes & 2.6 & 0.7 & 1.6 & $0.2^{3}$ & 3.5 & 2.7 & 2.4 & 1.3 \\
\hline Panicum virgatum & 3.1 & 6.9 & 4.2 & $16.4^{1}$ & 1.6 & 1.4 & 1.1 & 1.4 \\
\hline Poa pratensis & 1.2 & 0 & 4.2 & $0.1^{2}$ & 26.1 & $0.8^{3}$ & 11.4 & $3.3^{2}$ \\
\hline Schizachyrium scoparium & 15.0 & 21.2 & 9.6 & 10.6 & 2.5 & 4.4 & 1.4 & 7.2 \\
\hline Sorghastrum nutans & 13.9 & $28.8^{1}$ & 11.5 & $52.6^{1}$ & 8.4 & $17.8^{1}$ & 11.5 & 22.9 \\
\hline Sporobolus compositus & 5.9 & $0.3^{2}$ & 5.6 & $0.4^{2}$ & 3.1 & 2.8 & 7.6 & 9.7 \\
\hline Sporobolus heterolepis & 1.6 & 1.0 & 1.1 & 0.6 & 1.6 & 1.0 & 4.6 & $10.4^{1}$ \\
\hline \multicolumn{9}{|l|}{ Forb and woody species } \\
\hline Ambrosia psilostachya & 0.9 & 1.3 & 3.3 & 2.5 & 0.8 & 0.6 & 1.3 & 3.9 \\
\hline Amorpha canescens & 3.4 & 3.4 & 2.8 & 4.0 & 3.4 & 2.9 & 6.5 & 7.6 \\
\hline Artemisia Iudoviciana & 0.7 & 0.1 & 1.9 & 0 & 5.1 & 3.5 & 1.3 & 0.7 \\
\hline Lespedeza capitata & 0 & 0.1 & 0.8 & 3.6 & 0.7 & 0.4 & 0.2 & 1.0 \\
\hline Lespedeza violacea & 0 & 0 & 2.7 & $19.1^{2}$ & 0 & 0.2 & 0.7 & 2.5 \\
\hline Oligoneuron rigidum & 0 & 0 & 0.5 & 2.9 & 0 & 0.1 & 0.3 & 2.1 \\
\hline Physalis pumila & 0.8 & 0.6 & 2.2 & 0.8 & 3.4 & 1.5 & 2.3 & 1.1 \\
\hline Rhus glabra & 0.1 & 0.1 & 0.7 & 0.3 & 7.4 & 11.5 & 0.5 & 1.7 \\
\hline Ruellia humilis & 0.5 & 0.3 & 1.7 & 2.1 & 0.6 & 0.3 & 3.5 & 0.4 \\
\hline Salvia azurea & 5.5 & 4.0 & 0 & 0 & 1.2 & 2.8 & 0.1 & 0.2 \\
\hline Solidago canadensis & 0 & 0 & 6.4 & 9.0 & 0.1 & 0.1 & 4.9 & $12.6^{2}$ \\
\hline Solidago missouriensis & 2.2 & 0.5 & 2.4 & 0.6 & 0.7 & 2.0 & 3.5 & $14.0^{1}$ \\
\hline Symphyotrichum ericoides & 4.1 & 0.7 & 1.5 & 0.1 & 4.6 & $19.8^{2}$ & 5.3 & $33.0^{1}$ \\
\hline Symphyotrichum oblongifolium & 3.1 & 1.6 & 0 & 0 & 2.1 & $9.7^{1}$ & 0 & 0 \\
\hline
\end{tabular}

${ }^{1}$ Significant $(P<0.05)$ increase from 1994.

${ }^{2}$ Marginally significant $(P<0.10)$.

${ }^{3}$ Significant $(P<0.05)$ decrease from 1994.

when cover dramatically increased in the summer-burned watersheds (Fig. 1D). With spring burning, sedge cover on lowland sites declined abruptly after the second burn and then stabilized (Fig. 1D), but remained constant through time at low levels on upland sites (data not shown). After $14 \mathrm{yr}$, sedge cover averaged $21.9 \pm 0.1 \%$ in summer-burned watersheds, compared to $2.2 \pm 0.1 \%$ in spring-burned watersheds. The response of Kentucky bluegrass (Poa pratensis L.) cover to burn season also varied with topographic position. On upland sites, bluegrass cover decreased linearly from both summer and spring burning with slopes that differed significantly (Fig. 1E); whereas on lowland sites, the curvature of decline for bluegrass was quadratic for both burn treatments (data not shown). At the onset of the study, bluegrass levels were significantly lower in the spring-burned watersheds $(2.4 \pm 0.1 \%)$ than in the summer-burned watersheds $(18.1 \pm 0.1 \%)$, but after $14 \mathrm{yr}$, remnant amounts of bluegrass remained in both burn treatments. Canopy cover of Scribner's panicum (Dichanthelium oligosanthes [Nash] Gould), the most common coolseason grass on Konza Prairie, declined over time with both burn treatments, although the downward trend was curvilinear in the summer-burned watersheds and linear in the springburned watersheds (Fig. 1F). Other cool-season grass species $(n=7)$ were too low $(<1 \%)$ for meaningful cover analysis, but all persisted throughout the study in both burn treatments.

Cover of prairie junegrass (Koeleria macrantha [Ledeb.] Schult.) was $<1 \%$ and did not change over time $(P>0.05)$ with summer burning, but its frequency of occurrence on upland topographic positions increased significantly from $5.0 \%$ in 1994 to $73.5 \%$ in 2007 (Table 2). The frequency of other cool-season grasses did not differ significantly between 1994 and 2007 with either burning treatment, although the reduction in Kentucky bluegrass in spring-burned upland sites (from $79.6 \%$ to $0 \%$ ) was nearly significant $(P<0.08)$.

\section{Perennial Forbs}

Heath aster (Symphyotrichum ericoides [L.] Nesom) exhibited the strongest immediate response of all species to summer burning, increasing from $5.0 \pm 0.1 \%$ cover in 1994 to $26.1 \pm 0.1 \%$ cover in 1995 . Thereafter, cover of heath aster fluctuated at levels significantly higher than in the springburned watersheds, although neither linear nor curvilinear 
Table 2. Frequency of occurrence comparisons between the first and last year of the study in spring-burned and summer-burned ungrazed tallgrass prairie on upland and lowland topographic positions for those perennial species with $>20 \%$ frequency. Frequency values are based on occurrence in $10-\mathrm{m}^{2}$ plots $(n=40)$.

\begin{tabular}{|c|c|c|c|c|c|c|c|c|}
\hline \multirow[b]{3}{*}{ Species } & \multicolumn{4}{|c|}{ Spring-burned (\%) } & \multicolumn{4}{|c|}{ Summer-burned (\%) } \\
\hline & \multicolumn{2}{|c|}{ Uplands } & \multicolumn{2}{|c|}{ Lowlands } & \multicolumn{2}{|c|}{ Uplands } & \multicolumn{2}{|c|}{ Lowlands } \\
\hline & 1994 & 2007 & 1994 & 2007 & 1994 & 2007 & 1994 & 2007 \\
\hline \multicolumn{9}{|l|}{ Graminoids } \\
\hline Andropogon gerardii & 100 & 100 & 100 & 100 & 100 & 100 & 100 & 100 \\
\hline Bouteloua curtipendula & 100 & 97.4 & 33.4 & 28.8 & 67.7 & 91.8 & 24.8 & $40.0^{1}$ \\
\hline Dichanthelium acuminatum & 2.6 & 1.3 & 17.3 & 5.3 & 1.3 & 1.3 & 17.3 & 37.2 \\
\hline Dichanthelium oligosanthes & 90.3 & 87.6 & 91.8 & 47.5 & 87.1 & 90.3 & 96.1 & 98.7 \\
\hline Eragrostis spectabilis & 45.0 & 71.2 & 16.8 & 73.5 & 1.3 & 1.3 & 1.3 & 9.4 \\
\hline Koeleria macrantha & 3.9 & 29.9 & 7.3 & 13.4 & 5.0 & $73.5^{1}$ & 1.3 & $32.5^{2}$ \\
\hline Panicum virgatum & 39.9 & 45.0 & 42.4 & 50.0 & 35.8 & 36.6 & 32.3 & 37.3 \\
\hline Poa pratensis & 79.6 & $0^{2}$ & 85.4 & 11.3 & 100 & 60.2 & 80.7 & 62.5 \\
\hline Schizachyrium scoparium & 90.0 & 95.0 & 67.7 & $97.4^{1}$ & 34.2 & $61.7^{2}$ & 27.4 & $78.0^{1}$ \\
\hline Sorghastrum nutans & 100 & 100 & 100 & 100 & 74.6 & $94.7^{1}$ & 93.3 & 96.1 \\
\hline Sporobolus compositus & 76.7 & 42.4 & 94.7 & 93.3 & 50.0 & 79.6 & 92.7 & $100^{1}$ \\
\hline Sporobolus heterolepis & 27.8 & 30.2 & 14.6 & 19.0 & 8.2 & 16.5 & 27.5 & $45.0^{2}$ \\
\hline \multicolumn{9}{|l|}{ Forb and woody species } \\
\hline Achillea millefolium & 25.0 & 3.9 & 26.5 & $3.9^{3}$ & 32.5 & 28.8 & 3.9 & $19.0^{2}$ \\
\hline Ambrosia psilostachya & 42.0 & 77.5 & 100 & 100 & 42.5 & 52.5 & 52.5 & $92.7^{1}$ \\
\hline Amorpha canescens & 63.4 & 63.4 & 45.2 & 56.3 & 64.2 & 67.8 & 82.6 & 82.6 \\
\hline Artemisia Iudoviciana & 27.6 & $3.9^{3}$ & 60.2 & $3.9^{2}$ & 91.8 & 91.8 & 52.5 & 57.6 \\
\hline Asclepias stenophylla & 1.3 & $19.0^{1}$ & 9.4 & 9.4 & 2.6 & 5.3 & 15.4 & 7.3 \\
\hline Asclepias syriaca & 0 & 0 & 15.0 & $50.0^{2}$ & 1.3 & 0 & 42.5 & $1.3^{3}$ \\
\hline Asclepias verticillata & 15.4 & 32.2 & 57.8 & $82.7^{1}$ & 3.9 & 3.9 & 9.4 & 19.0 \\
\hline Asclepias viridis & 25.4 & 25.6 & 55.1 & 76.6 & 39.5 & 24.8 & 32.3 & 10.0 \\
\hline Baptisia bracteata & 0 & 0 & 2.6 & 3.9 & 50.0 & 47.4 & 17.4 & 17.4 \\
\hline Brickellia eupatorioides & 80.2 & $20.0^{3}$ & 2.6 & 2.6 & 24.3 & $57.5^{1}$ & 11.3 & 65.1 \\
\hline Ceanothus herbaceus & 14.6 & 14.6 & 1.3 & 1.3 & 25.4 & 27.6 & 1.3 & 1.3 \\
\hline Cirsium undulatum & 2.6 & 1.3 & 0 & 0 & 12.4 & 34.7 & 0 & 0 \\
\hline Dalea candida & 7.3 & 22.5 & 47.3 & 77.5 & 5.3 & 9.7 & 8.2 & 32.3 \\
\hline Dalea purpurea & 46.2 & 72.2 & 0 & 0 & 34.7 & 56.3 & 1.3 & $17.4^{1}$ \\
\hline Lespedeza capitata & 5.0 & 21.4 & 32.3 & $78.9^{1}$ & 15.0 & 25.0 & 8.2 & 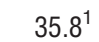 \\
\hline Lespedeza violacea & 0 & 1.3 & 27.5 & $65.1^{2}$ & 0 & 2.6 & 9.4 & $39.0^{2}$ \\
\hline Lomatium foeniculaceum & 16.5 & 2.6 & 0 & 0 & 9.7 & 16.5 & 0 & 0 \\
\hline Mimosa nuttallii & 24.3 & $47.4^{1}$ & 9.4 & 12.4 & 8.2 & 8.2 & 2.6 & 2.6 \\
\hline Oligoneuron rigidum & 0 & 0 & 19.0 & 23.4 & 0 & $9.4^{1}$ & 6.7 & 32.5 \\
\hline Oxalis stricta & 20.4 & 7.3 & 61.8 & 45.0 & 1.3 & 22.0 & 16.8 & 58.0 \\
\hline Oxalis violacea & 0 & 0 & 47.0 & 55.0 & 0 & 0 & 8.2 & 9.4 \\
\hline Pediomelum esculentum & 0 & 3.9 & 0 & 0 & 5.3 & 20.4 & 1.3 & 0 \\
\hline Physalis pumila & 35.8 & $58.0^{2}$ & 72.5 & 95.0 & 62.5 & 72.8 & 62.9 & 87.6 \\
\hline Psoralidium tenuiflorum & 7.3 & 7.3 & 1.3 & 8.2 & 11.4 & 10.0 & 9.4 & 23.4 \\
\hline Rhus glabra & 1.3 & 3.9 & 16.8 & 27.2 & 50.0 & 50.0 & 6.7 & 14.6 \\
\hline Ruellia humilis & 58.4 & 56.3 & 62.7 & 81.0 & 44.8 & 66.6 & 92.7 & 70.1 \\
\hline Salvia azurea & 75.2 & 78.0 & 1.3 & 0 & 62.9 & $81.0^{1}$ & 15.0 & 20.0 \\
\hline Solidago canadensis & 0 & 0 & 47.5 & 47.5 & 2.6 & 2.6 & 47.0 & $66.6^{2}$ \\
\hline Solidago missouriensis & 26.5 & 42.0 & 27.5 & 37.5 & 11.3 & 20.4 & 41.6 & $74.4^{1}$ \\
\hline Symphyotrichum ericoides & 91.8 & 80.2 & 53.8 & 17.3 & 90.0 & 100 & 96.1 & 100 \\
\hline Symphyotrichum oblongifolium & 86.6 & 88.7 & 0 & 1.3 & 52.8 & 72.2 & 0 & 0 \\
\hline Tragia betonicifolia & 14.6 & $30.2^{2}$ & 0 & 0 & 22.6 & 27.6 & 0 & 0 \\
\hline Vernonia baldwinii & 34.7 & 39.8 & 47.3 & 68.9 & 47.3 & 60.2 & 65.0 & 87.1 \\
\hline
\end{tabular}

${ }^{1}$ Significant $(P<0.05)$ increase from 1994.

${ }^{2}$ Marginally significant $(P<0.10)$.

${ }^{3}$ Significant $(P<0.05)$ decrease from 1994. 

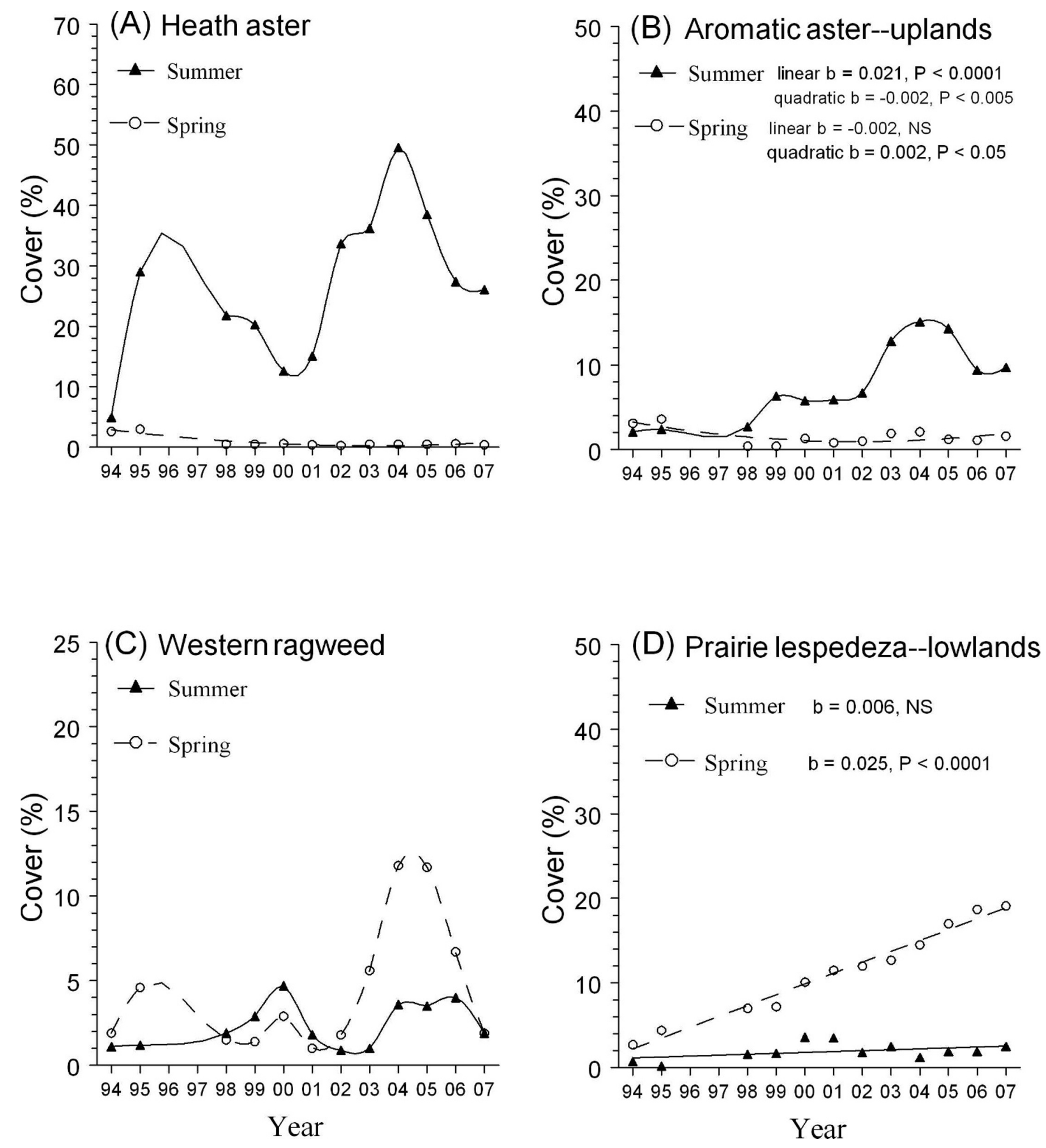

Figure 2. Temporal trends in canopy cover for various perennial forb species in response to summer and spring burning of ungrazed tallgrass prairie. For those graphs that are for a specific topographic position, the values for each burn treatment represent the mean of 40 plots; otherwise, the values represent the mean of 80 plots from the combined upland and lowland topographic positions in two watersheds. Data for 1996 and 1997 are excluded because of a wildfire. Scaling of the $y$-axis varies among graphs.

response curves adequately depicted the temporal fluctuations (Fig. 2A). Aromatic aster (Symphyotrichum oblongifolium [Nutt.] Nesom), a congener that is restricted to upland sites, also fluctuated inconsistently over time from summer burning, and although the linear and quadratic response curves were significant $(P<0.005)$, both were poor characterizations of the temporal changes in cover (Fig. 2B). Unlike the response in heath aster, the increase in aromatic aster cover from summer burning 
Table 3. Temporal variation in the frequency of the most commonly occurring annual forbs in summer-burned and spring-burned ungrazed watersheds. Frequency values are based on occurrence in $10-\mathrm{m}^{2}$ plots $(n=80)$ averaged over upland and lowland topographic positions, except for the denoted site-specific species $(\mathrm{L}=$ lowlands), in which case $n=40$.

\begin{tabular}{|c|c|c|c|c|c|c|c|c|c|c|c|c|}
\hline \multirow[b]{2}{*}{ Species } & \multicolumn{12}{|c|}{ Year (\%) } \\
\hline & 1994 & 1995 & 1998 & 1999 & 2000 & 2001 & 2002 & 2003 & 2004 & 2005 & 2006 & 2007 \\
\hline \multicolumn{13}{|l|}{ Summer-burned } \\
\hline Acalypha virginica $(\mathrm{L})$ & 0 & 0 & 0 & 1.3 & 0 & 1.3 & 0 & 0 & 0 & 0 & 3.9 & 0 \\
\hline Ambrosia artemisiifolia $(\mathrm{L})$ & 1.3 & 19.3 & 1.3 & 1.3 & 2.6 & 0 & 0 & 0 & 2.6 & 0 & 5.3 & 0 \\
\hline Chamaesyce glyptosperma & 0 & 0 & 0 & 0 & 0 & 0 & 2.8 & 0 & 0.3 & 0 & 9.7 & 0 \\
\hline Chamaesyce nutans $(\mathrm{L})$ & 0 & 0 & 0 & 0 & 0 & 0 & 0 & 0 & 0 & 0 & 0 & 0 \\
\hline Conyza canadensis & 1.3 & 9.6 & 0.6 & 20.7 & 39.5 & 0 & 2.9 & 42.2 & 73.6 & 0.6 & 51.8 & 20.2 \\
\hline Erigeron strigosus & 0 & 0.3 & 0 & 1.9 & 0 & 1.9 & 0 & 0 & 11.9 & 8.5 & 14.9 & 14.5 \\
\hline Euphorbia marginata & 3.2 & 29.3 & 0.3 & 0 & 4.4 & 0 & 1.0 & 0 & 5.5 & 0 & 1.3 & 0 \\
\hline Euphorbia spathulata & 8.3 & 65.4 & 15.8 & 38.3 & 18.8 & 4.6 & 36.2 & 31.8 & 55.1 & 5.0 & 67.8 & 6.3 \\
\hline Krigia cespitosa $(\mathrm{L})$ & 0 & 0 & 0 & 0 & 0 & 0 & 0 & 0 & 0 & 0 & 0 & 0 \\
\hline Lepidium densiflorum & 0 & 48.4 & 27.8 & 6.3 & 44.6 & 7.2 & 38.5 & 53.8 & 57.6 & 4.0 & 56.4 & 10.5 \\
\hline Linum sulcatum & 4.4 & 21.5 & 57.6 & 47.2 & 68.4 & 17.1 & 67.4 & 78.7 & 89.3 & 27.7 & 95.5 & 13.5 \\
\hline Plantago rhodosperma & 0 & 1.3 & 0 & 7.5 & 2.8 & 0 & 0.3 & 4.4 & 16.1 & 1.3 & 27.9 & 8.7 \\
\hline Silene antirrhina & 0.3 & 53.8 & 77.7 & 52.1 & 85.2 & 16.6 & 25.3 & 81.5 & 82.2 & 0.3 & 83.0 & 43.5 \\
\hline Spermolepis inermis & 0 & 13.2 & 7.1 & 15.1 & 31.3 & 5.1 & 6.2 & 21.3 & 20.2 & 3.2 & 19.6 & 24.4 \\
\hline Triodanis perfoliata & 2.9 & 27.3 & 1.9 & 19.4 & 7.3 & 0 & 0.3 & 17.4 & 21.3 & 1.3 & 25.5 & 9.5 \\
\hline Viola bicolor & 0 & 54.7 & 0.3 & 0 & 36.9 & 0 & 0.6 & 4.5 & 6.9 & 2.9 & 22.2 & 0.3 \\
\hline \multicolumn{13}{|l|}{ Spring-burned } \\
\hline Acalypha virginica (L) & 1.3 & 1.3 & 2.6 & 5.3 & 11.4 & 16.8 & 11.4 & 29.5 & 17.4 & 13.4 & 19.0 & 34.2 \\
\hline Ambrosia artemisiifolia (L) & 3.9 & 30.0 & 1.3 & 10.0 & 1.3 & 1.3 & 22.5 & 11.4 & 2.6 & 17.4 & 15.0 & 24.8 \\
\hline Chamaesyce glyptosperma & 0 & 0 & 7.0 & 0 & 0 & 21.0 & 48.0 & 53.4 & 23.3 & 18.2 & 72.4 & 89.3 \\
\hline Chamaesyce nutans $(\mathrm{L})$ & 0 & 0 & 5.0 & 25.0 & 5.0 & 12.5 & 10.0 & 25.0 & 15.0 & 0 & 15.0 & 20.0 \\
\hline Conyza canadensis & 0 & 0 & 0 & 0 & 0 & 0 & 0 & 0 & 4.0 & 0 & 1.9 & 0 \\
\hline Erigeron strigosus & 1.3 & 14.8 & 7.0 & 4.6 & 12.2 & 19.8 & 13.7 & 8.3 & 28.5 & 13.4 & 37.0 & 37.4 \\
\hline Euphorbia marginata & 3.2 & 7.2 & 0.3 & 0.3 & 0.3 & 1.9 & 0.3 & 0.3 & 2.4 & 0.6 & 0 & 0.3 \\
\hline Euphorbia spathulata & 0 & 0.3 & 0 & 0 & 0 & 0.3 & 0 & 0 & 0 & 7.5 & 0 & 0 \\
\hline Krigia cespitosa $(\mathrm{L})$ & 5.0 & 22.5 & 2.5 & 0 & 7.5 & 2.5 & 0 & 17.5 & 27.5 & 0 & 30.0 & 27.5 \\
\hline Lepidium densiflorum & 0.6 & 0.6 & 0 & 0.3 & 0 & 0.3 & 0 & 1.0 & 0 & 0 & 1.0 & 1.0 \\
\hline Linum sulcatum & 0 & 24.1 & 0.6 & 8.8 & 5.1 & 0.3 & 0.3 & 4.4 & 8.6 & 0.3 & 0.3 & 0 \\
\hline Plantago rhodosperma & 0 & 2.4 & 0 & 0 & 0 & 0 & 0 & 0.3 & 1.7 & 0 & 1.3 & 1.0 \\
\hline Silene antirrhina & 0 & 0.3 & 0 & 0 & 0 & 0 & 0 & 0 & 0 & 0 & 0 & 0 \\
\hline Spermolepis inermis & 0 & 0 & 0 & 0 & 0 & 0 & 0 & 0 & 0 & 0 & 0 & 0 \\
\hline Triodanis perfoliata & 0 & 0.3 & 0 & 0 & 0 & 0 & 0 & 0 & 0 & 0 & 0 & 0 \\
\hline Viola bicolor & 0 & 0 & 0 & 0 & 0 & 0 & 0 & 0 & 0 & 0 & 0 & 0 \\
\hline
\end{tabular}

was not immediate, but eventually increased from $2.1 \pm 0.1 \%$ in 1994 to $9.7 \pm 0.1 \%$ in 2007 . In spring-burned watersheds, both heath aster and aromatic aster followed small but significant curvilinear declines in cover. Burn season did not differentially affect the canopy cover of western ragweed (Ambrosia psilostachya DC), which exhibited large and inconsistent temporal fluctuations in both treatments (Fig. 2C). Three subdominant forbs, Louisiana sagewort (Artemisia ludoviciana Nutt.), Missouri goldenrod (Solidago missouriensis Nutt.), and prairie ground-cherry (Physalis pumila Nutt.), also fluctuated with alternating intervals of decline and recovery over time in summer-burned sites, but remained stable at low levels in the spring-burned watersheds (data not shown). Canopy cover of prairie lespedeza (Lespedeza violaceae [L.] Pers.), a species that occurs predominantly on lowland sites, did not change over time with summer burning, but was the only forb species that increased $(P<0.0001)$ with spring burning (Fig. 2D).
Summer burning significantly increased the frequency of seven perennial forb species between 1994 and 2007, whereas common milkweed (Asclepias syriaca L.) was the only perennial forb that declined significantly in frequency (Table 2). In comparison, the frequency of four perennial forbs increased significantly and three perennial forbs decreased significantly in response to spring burning (Table 2).

\section{Annuals}

Frequency of annual forb species fluctuated inconsistently through time in both burn seasons (Table 3). The only annual grasses that appeared during the study, Japanese brome (Bromus japonicus Thunb.), six-weeks fescue (Vulpia octoflora [Walter] Rydb.), and common witchgrass (Panicum capillare L.) rarely occurred in either burn treatment. 

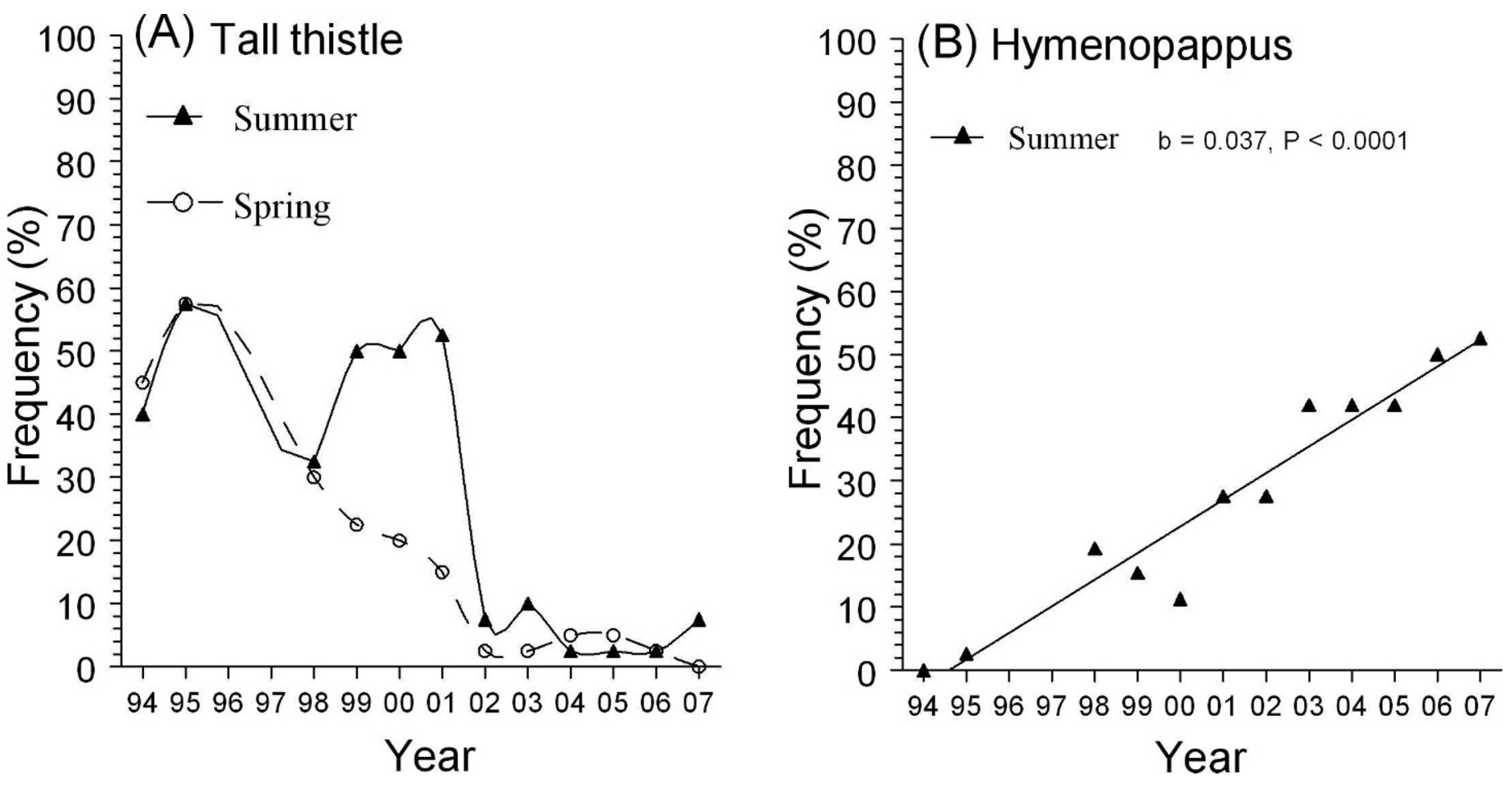

Figure 3. Temporal trends in the frequency of two biennial forb species in response to summer and spring burning of ungrazed tallgrass prairie: $\mathbf{A}$, tall thistle on lowlands topographic position; B, white-bract hymenopappus in summer-burned uplands topographic position (plants never appeared in the spring-burned sites). Values for each burn treatment represent the mean of 40 plots in two watersheds. Data for 1996 and 1997 are excluded because of a wildfire.

\section{Biennial Forbs}

The frequency of tall thistle (Cirsium altissimum [L.] Sprent.) declined significantly in response to both summer and spring burning, although the temporal reductions were not linear and it required multiple burns in either season before levels dropped to $<10 \%$ occurrence (Fig. $3 \mathrm{~A}$ ). In contrast, the frequency of white-bract hymenopappus (Hymenopappus scabiosaeus L'Her.), a biennial forb that occurs only on upland soils, increased linearly $(P<0.0001)$ over time with summer burning (from $0 \%$ in 1994 to $52.6 \%$ in 2007), but never appeared in spring-burned sites (Fig. 3B). Occurrence of the seven other biennial forb species that appeared sporadically throughout the study was too low for meaningful analysis.

\section{Woody Species}

Canopy cover (Table 1) and frequency (Table 2) of the two dominant shrubs in the watersheds (smooth sumac [Rhus glabra L.] and leadplant [Amorpha canescens Pursh]) did not change over time $(P>0.10)$ in response to either spring or summer burning. Other woody species $(n=6)$ that occurred in the watersheds averaged $<1 \%$ cover and also did not change over time in either burn treatment.

\section{Diversity Metrics}

Trends in species richness and Shannon's diversity index were not differentially influenced by topographic position for either burn treatment. Diversity increased linearly over time $(P<0.001)$ with summer burning, but declined initially and then stabilized with spring burning (Fig. 4A). Species richness increased with summer burning $(P<0.0001)$, but did not change through time with annual spring burning (Fig. 4B). After $14 \mathrm{yr}$, species richness was $28 \%$ higher in prairie that was burned in the summer $(n=73.0 \pm 2.6)$ than in prairie that was burned in the spring $(n=57.3 \pm 2.1)$.

Richness of the various life-form components did not change significantly over time from spring burning, but summer burning caused large and inconsistent temporal fluctuations in the number of annual forb species (Fig. 4C). After the initial burns in 1994, the number of annual forbs was significantly higher in summer-burned than in spring-burned watersheds in all years except 2001. The number of perennial forb species increased $(P<0.001)$ with repeated summer burning (from $31.0 \pm 1.8$ in 1994 to $36.5 \pm 1.8$ in 2007), whereas perennial forb richness did not change over time in response to spring burning (Fig. 4D).

\section{DISCUSSION}

Over the 14-yr sampling period, we detected 149 species in the summer-burned watersheds and 128 species in the spring-burned watersheds. Repeated summer burning was a significant driving force in relatively few perennial species, perhaps because of the benign fire intensity from the high amounts of green tissue present. Summer burning, however, caused large temporal fluctuations in the cover of some species, and their inconsistent response patterns and nonlinear trends may explain discrepancies that have been observed in other, short-term, studies.

The increase in big bluestem and Indiangrass cover from repeated burning in either season reflects their adaptability to 

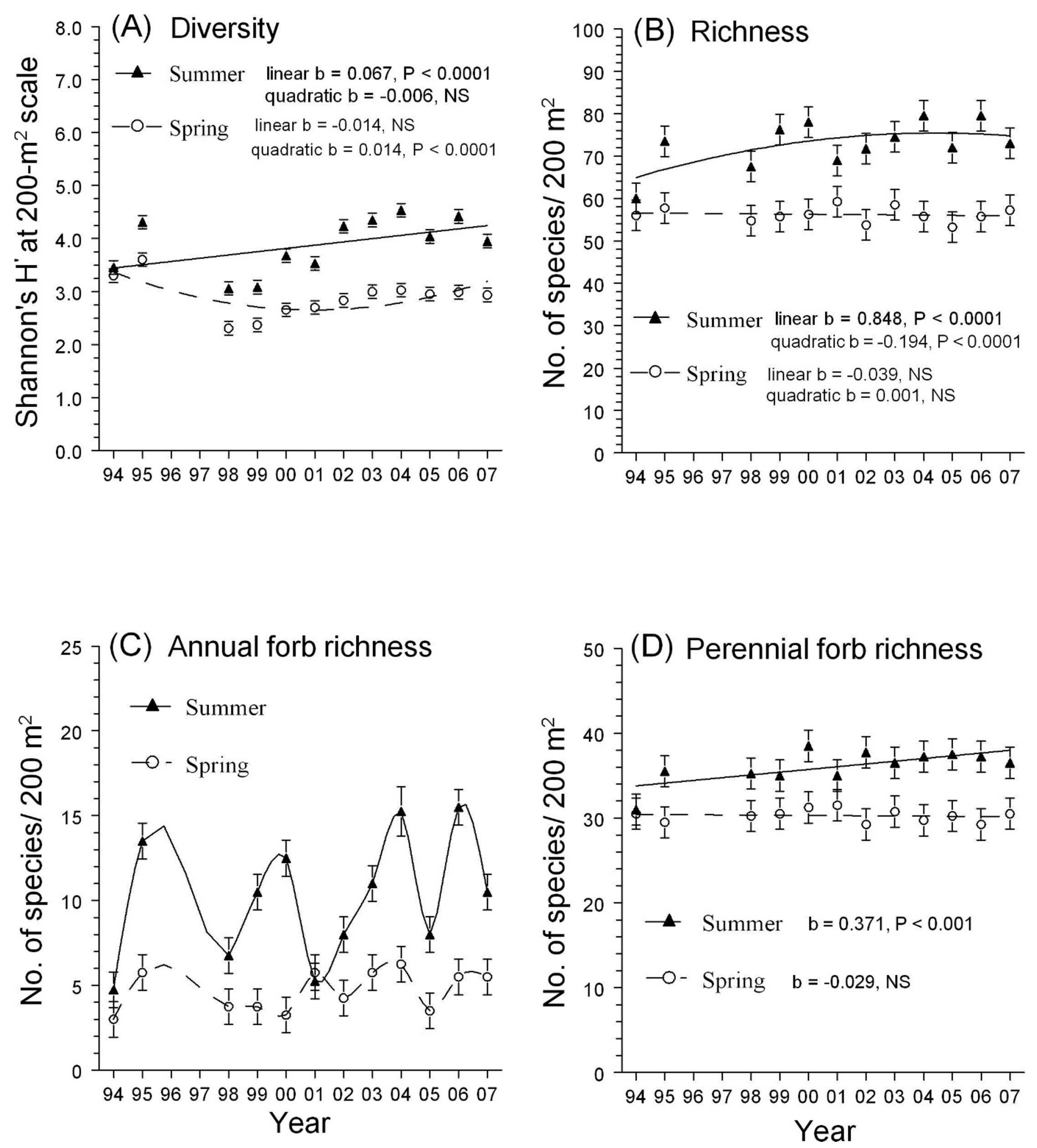

Figure 4. Temporal trends in plant species diversity metrics from summer and spring burning of ungrazed tallgrass prairie: A, Shannon's diversity index; B, species richness; C, annual forb richness; and D, perennial forb richness. Values for each burn treatment represent the mean of 80 plots from the combined upland and lowland topographic positions in two watersheds. Error bars represent \pm 1 SE. Data for 1996 and 1997 are excluded because of a wildfire. Scaling of the $y$-axis varies among graphs. 
thriving in a pyrogenic habitat. Similarly, little bluestem tolerated both spring and summer burns without significant changes in cover. We have previously documented that those species were differentially favored by annual burning in the dormant season, with big bluestem increasing from fire in any season, little bluestem increasing with autumn and winter burns, and Indiangrass increasing with spring burns (Towne and Kemp 2003). The temporal stability of little bluestem to recurring summer fire contrasts with its response in other areas where it has declined with growing-season burns (Ewing and Engle 1988; Engle et al. 1993; Volesky and Connot 2000). Because little bluestem is more sensitive to fire when fuel loads are high (Ewing and Engle 1988), litter accumulations and/or burn conditions in this study may have been insufficient to produce the highintensity fires that are usually detrimental to cespitose grasses. The large but nonsignificant increase in side-oats grama cover from summer burning also differs from its response in monoculture plots, where several years were required before the plant recovered to preburn conditions (Ansley et al. 2006). In our study, the response of side-oats grama was highly variable and inconsistent between replications. Side-oats grama cover remained stable through time in the watershed that had deep upland soils, but dramatically increased in the watershed that had shallower and rockier upland soils, suggesting that topoedaphic factors may be an important variable in how sideoats grama responds to summer burning.

The decline in Kentucky bluegrass and the temporal stability of other cool-season grass species to summer fire also differs from other research that found cool-season grasses increase with summer burning (Howe 1994, 1995; Engle et al. 1998). However, the cool-season grasses that have increased after summer burning in some studies (Howe 1994, 1995) were aggressive exotic species (e.g., quackgrass [Elymus repens $\{\mathrm{L}$. Gould] and reed canarygrass [Phalaris arundinacea L.]), which were absent in our prairie. Most of the native cool-season grasses that persist in tallgrass prairie apparently are tolerant of summer fire, but are not favored by it.

Burning in the late growing season has been suggested as a way to increase the number and cover of spring-flowering species (Howe 1994, 1995; Copeland et al. 2002). Howe (1995) theorized that summer burning should disadvantage late-season species by destroying aboveground tissue, thereby favoring early-season flowering species that had finished their growth and reproduction. In our study, however, the only perennial forbs that consistently increased in cover with summer burning were species that flower late in the growing season (e.g., aster species). Comparatively, these forbs declined over time with spring burning. Significant increases in the cover of asters and the two dominant warm-season grasses (big bluestem and Indiangrass) indicate that inflorescence destruction and any potential drain in resources to regrow after summer fire did not suppress their competitiveness.

Species richness and diversity increased with summer burning primarily because of annual forb proliferation. Removing the litter layer with summer fire likely created a favorable seedbed for many annual species the next year. Dynamic temporal fluctuations in the frequency of annual forbs, however, indicate that other factors (e.g., precipitation patterns) also were influencing their establishment. Many of the annual forb species that appeared in the summer burned watersheds were native prairie species that are sensitive to dormant-season fire (Towne and Kemp 2003). Spring burning, however, did not eliminate all annual forb species, and a suite of annual forbs that seldom appeared in the summer burn treatment persisted in the spring-burned watersheds (e.g., dwarf-dandelion [Krigia cespitosa \{Raf.\} Chambers], eyebane [Chamaesyce nutans \{Lag.\} Small], ridge-seed mat-spurge [Chamaesyce glyptosperma \{Engelm.\} Small], and Virginia copperleaf [Acalypha virginica L.]).

In contrast to the increase in annual forbs, annual grasses did not change over time from summer burning. The inability of annual grasses to proliferate, however, was not due to limited seed sources because Japanese brome, six-weeks fescue, and numerous other annual grass species were abundant in nearby grazed watersheds. In studies elsewhere, annual grasses have been reported to increase after summer burning (Ewing and Engle 1988; Coppedge et al. 1998).

Summer burning has been considered to be a potential managerial tool to reduce woody vegetation (Adams et al. 1982), but we found that repeated burning of tallgrass prairie in the growing season was ineffective in reducing the cover or frequency of any shrub species. Although shrub mortality is influenced by fire intensity, woody species were not affected by summer burning even in lowland topographic positions where higher fuel loads would presumptively produce more intense fires. However, if we had conducted the summer burning under more extreme (and inherently more dangerous) conditions (i.e., higher wind speed, lower humidity, drought-stressed vegetation, or greater litter accumulation), hotter fire temperatures may have been able to inflict mortality on some of the shrubs.

\section{MANAGEMENT IMPLICATIONS}

Grasslands that are managed for traditional grazing operations generally are not intentionally burned in the growing season; however, burning discrete patches in the summer to create a shifting mosaic could provide high-quality regrowth to animals at a time when forage quality is typically declining (Fuhlendorf and Engle 2001, 2004). In grazed prairies, lower fuel loads and incomplete burning will likely dampen the response patterns of many species to summer fire that we observed in this ungrazed study. However, any vegetational changes from summer burning in grazed prairies will likely be confounded with the interactive influence of intense herbivory in the burned site (Coppedge et al. 1998, Engle and Bidwell 2001).

Based on this long-term study, the primary responses from burning ungrazed tallgrass prairie in the summer were an increased number of annual forbs and the proliferation of aster species, with no concomitant reduction in the dominance of the warm-season grasses. Although we found few negative responses to summer burning within the plant community, burning large tracts of ungrazed prairie in the summer could potentially have adverse repercussions on other biota that we did not examine in this study (e.g., invertebrates, reptiles, birds, or small mammals). However, the temporal increases in floristic richness and diversity from fire in the growing season compared with fire in the dormant season suggest that burning ungrazed prairie in the summer could function as a surrogate for moderate grazing to increase heterogeneity. 


\section{LITERATURE CITED}

Abrams, M. D., and L. C. Hulbert. 1987. Effect of topographic position and fire on species composition in tallgrass prairie in northeast Kansas. American Midland Naturalist 17:442-445.

Adams, D. E., R. C. Anderson, and S. L. Collins. 1982. Differential response of woody and herbaceous species to summer and winter burning in an Oklahoma grassland. Southwestern Naturalist 27:55-61.

Aldous, A. E. 1934. Effect of burning on Kansas bluestem pastures. Topeka, KS, USA: Kansas Agriculture Experiment Station Bulletin 38. 65 p.

Anderson, K. L., E. F. Smith, and C. E. Owensby. 1970. Burning bluestem range. Journal of Range Management 23:81-92.

Ansley, R. J., M. J. Castellano, and W. E. Pinchak. 2006. Sideoats grama growth responses to seasonal fires and clipping. Rangeland Ecology and Management 59:258-266.

Balley, A. W., and C. E. Poulton. 1968. Plant communities and environmental interrelationships in a portion of the Tillamook Burn, northwestern Oregon. Ecology 49:1-13.

BragG, T. B. 1982. Seasonal variations in fuel and fuel consumption by fires in a bluestem prairie. Ecology 63:7-11.

Bragg, T. B., and L. C. Hulbert. 1976. Woody plant invasion of unburned Kansas bluestem prairie. Journal of Range Management 29:19-24.

Colıins, S. L. 1992. Fire frequency and community heterogeneity in tallgrass prairie vegetation. Ecology 73:2001-2006.

Copeland, T. E., W. Sluis, and H. F. Howe. 2002. Fire season and dominance in an Illinois tallgrass prairie restoration. Restoration Ecology 10:315-323.

Coppedge, B. R., D. M. Engle, C. S. Toepfer, and J. H. Shaw. 1998. Effects of seasonal fire, bison grazing and climatic variation on tallgrass prairie vegetation. Plant Ecology 139:235-246.

Emery, S. M., And K. L. Gross. 2005. Effects of timing of prescribed fire on the demography of an invasive plant, spotted knapweed Centaurea maculosa. Journal of Applied Ecology 42:60-69.

Engle, D. M., And T. G. Bidwell. 2001. Viewpoint: the response of central North American prairies to seasonal fire. Journal of Range Management 54:2-10.

Engle, D. M., R. L. Mitchell, and R. L. Stevens. 1998. Late growing-season fire effects in mid-successional tallgrass prairies. Journal of Range Management $51: 115-121$.

Engle, D. M., M. W. Palmer, J. S. Crockett, R. L. Mitchell, and R. Stevens. 2000. Influence of late season fire on early successional vegetation of an Oklahoma prairie. Journal of Vegetation Science 11:135-144.

Engle, D. M., J. F. Stritzke, T. G. Bidwell, and P. L. Claypool. 1993. Late-summer fire and follow-up herbicide treatments in tallgrass prairie. Journal of Range Management 46:542-547.

Ewing, A. L., And D. M. Engle. 1988. Effects of late summer fire on tallgrass prairie microclimate and community composition. American Midland Naturalist 120:212-223.
Fuhlendorf, S. D., And D. M. Engle. 2001. Restoring heterogeneity on rangelands: ecosystem management based on evolutionary grazing patterns. BioScience $51: 625-632$.

Funlendorf, S. D., ANd D. M. Engle. 2004. Application of the fire-grazing interaction to restore a shifting mosaic on tallgrass prairie. Journal of Applied Ecology 41:604-614.

Gibson, D. J., AND L. C. Hulbert. 1987. Effects of fire, topography and year-to-year climatic variation on species composition in tallgrass prairie. Vegetatio 72:175-185

HIGGINs, K. F. 1984. Lightning fires in North Dakota grasslands and in the pinesavanna lands of South Dakota and Montana. Journal of Range Management $37: 100-103$.

Howe, H. F. 1994. Response of early- and late-flowering plants to fire season in experimental prairies. Ecological Applications 4:121-133.

HowE, H. F. 1995. Succession and fire season in experimental prairie plantings. Ecology 76:1917-1925.

Kindscher, K., AND L. L. Tieszen. 1998. Floristic and soil organic matter changes after five and thirty-five years of native tallgrass prairie restoration. Restoration Ecology 6:181-196.

Littell, R. C., G. A. Milliken, W. W. Stroup, R. D. Wolfinger, and O. Schabenberger. 2006. SAS for Mixed Models, 2nd ed. Cary, NC, USA: SAS Institute Inc. $840 \mathrm{p}$.

Parmenter, R. R. 2008. Long-term effects of a summer fire on desert grassland plant demographics in New Mexico. Rangeland Ecology and Management 61:156-168.

Polley, H. W., J. D. Derner, and B. J. Wilsey. 2005. Patterns of plant species diversity in remnant and restored tallgrass prairies. Restoration Ecology 13:480-487.

PYNE, S. J. 1994. Maintaining focus: an introduction to anthropogenic fire. Chemosphere 29:889-911.

Simmons, M. T., S. Windhager, P. Power, J. Lott, R. K. Lyons, and C. Schwope. 2007. Selective and non-selective control of invasive plants: the short-term effects of growing-season prescribed fire, herbicide, and mowing in two Texas prairies. Restoration Ecology 15:662-669.

Towne, E. G. 2002. Vascular plants of Konza Prairie Biological Station: an annotated checklist of species in a Kansas tallgrass prairie. Sida 20:269294.

Towne, E. G., And K. E. Kemp. 2003. Vegetation dynamics from annually burning tallgrass prairie in different seasons. Journal of Range Management $56: 185-192$

US Department of Agriculture Natural Resources Conservation Service. 2008. The PLANTS database. Available at: http//plants.usda.gov. Accessed 26 June 2008.

Volesky, J. D., AND S. B. Connot. 2000. Vegetation response to late growing-season wildfire on Nebraska Sandhills rangeland. Journal of Range Management 53:421-426. 